\title{
Effects of Regional Plyometric Trainings on Agility Performance of Male Volleyball Players
}

\author{
Mahmut Alp (Corresponding Author) \\ Department of Physical Education and Sports, Süleyman Demirel University \\ East Campus, 32260, Çünür-Isparta, Turkey
}

Tel: 90-246-211 $4760 \quad$ E-mail: mahmut.alp@windowslive.com

Mehmet Mansuroglu

Department of Sport Sciences, Süleyman Demirel University

East Campus, 32260, Çünür-Isparta, Turkey

Tel: 90-538-246-2662Ｅ-mail: mehmet.sdu.6030@gmail.com

$\begin{array}{lcc}\text { Received: April 10, } 2021 & \text { Accepted: May 13, } 2021 \quad \text { Published: May 31, } 2021 \\ \text { doi:10.5296/jei.v7i1.18525 } & \text { URL: https://doi.org/10.5296/jei.v7i1.18525 }\end{array}$

\begin{abstract}
The study aims to investigate the regional plyometric trainings' effects on the agility performance of male volleyball players. Süleyman Demirel University Volleyball Team with 20 players attended to the study voluntarily. Players were randomly divided into volleyball training group $(\mathrm{VTG})(\mathrm{n}=10)$ and plyometric training group $(\mathrm{PTG})(\mathrm{n}=10)$. As the VTG continued with their routine volleyball training; regional plyometric trainings for the lower extremity were performed to the PTG for 6 weeks, 3 days a week, at least 30 minutes a day in addition to volleyball training. $\mathrm{T}$ and Pro-Agility Tests were applied to the groups at the beginning and end of the 6-week period. Descriptive Statistics, Paired T-Test, and Independent T-Test were used for comparison. " $p<0.05$ " significance level was accepted for the results' evaluation. Results of comparison of the $\mathrm{T}$ and Pro-Agility pre and post tests' values of the groups, differences were statistically significant in PTG's values $p<0.05$ ), but no differences were found in VTG' values $(\mathrm{p}>0.05)$. Also, no differences were found as a result of the comparison of the pre and post $\mathrm{T}$ and Pro-Agility Test values between the groups $(\mathrm{p}>0.05)$. Considering that plyometric trainings provide maximum contraction in the shortest time possible and its effect on the characteristics like sudden changes of location and direction in the volleyball, applying plyometric trainings may be thought to be effective in
\end{abstract}


volleyball training programs.

Keywords: Plyometric, Agility, Volleyball

\section{Introduction}

Volleyball is one of the most popular sports of our age which is performed for both performance and recreational purposes is a very enjoyable sport played according to various rules. It drags large masses in Turkey as well as in the whole world. Professionally, with the international success of some of the Volleyball clubs and national teams, volleyball is taking firm steps towards becoming a global brand (Arslan, 2013).

Volleyball movements should generally be done quickly and explosively. The player needs power, speed, and agility for fast movements (Baacke, 2005). The performance expected from volleyball players is agility and speed capability for movement and skills to different sides in the playing field (Turnagöl, 1995). Agility is the effective combination of deceleration, direction change, and acceleration movements in a short time (Günay et al., 2017).

A high level of efficiency is demanded from the players due to the sprints in which the explosive force is exhibited, the vertical jump more than once for the attack, and the block where effective and fast movements are applied against the attack made by the opposing team, and the capacity to adapt to the course of the match for five sets (Aydoğan, 2006).

Plyometric training, which is defined as training that allows the muscle to contract with maximum force in the shortest possible time, can be described as fast dynamic loading or tension exercises in the involved muscle in response to strong muscle contraction. Plyometric movements are widely used in sports where force is used (Chu, 1992). Plyometric training is a method used to improve explosive power. Plyometric trainings have been used in training programs by trainers and players since their performance enhancing effect was seen. Generally, it is very useful in sports where rapid strength and jumping ability are used a lot (Radcliffe \& Faratinos, 1999; Muratl1, Şahin, \& Kalyoncu, 2005; Boreham, 2006).

In Volleyball, plyometric exercise includes jumping, jumping and limiting movements, besides shooting that is performed the explosive strength (Behm et al., 2008; Cappa \&Behm, 2013). These movements are also related to the development of agility (Craig, 2004; Miller et al., 2001; Young et al., 2001). In the light of the given literature information, this study aims to investigate the effects of regional plyometric trainings on the agility performances of male volleyball players.

\section{Method}

\subsection{Participants}

Süleyman Demirel University Volleyball Team with 20 players attended to the study voluntarily. Players were randomly divided into volleyball training group (VTG) $(n=10)$ and plyometric training group $(\mathrm{PTG})(\mathrm{n}=10)$. The mean age of the players was in VTG $20.60 \pm 1.37$, in PTG 21.10 \pm 2.11 years; mean height was in VTG 181.4 \pm 2.91 , PTG 
$182.50 \pm 3.63 \mathrm{~cm}$; mean weight was in VTG $78.4 \pm 6.64$, in PTG $77.5 \pm 4.54 \mathrm{~kg}$. The participants were verbally informed about the study method, and "Informed Consent Forms" were obtained from all players.

\subsection{Measures and Tests}

\subsubsection{Height Measurement}

The height was measured using a measuring tape with an accuracy of $1 \mathrm{~mm}$. The players stood in a flat body position on bare feet during the measurement. Values were recorded in cm (Alp \& Suna, 2020).

\subsubsection{Weight Measurement}

The weight was measured using a digital scale with a sensitivity of $0.001 \mathrm{~kg}$. The players also dressed lightly during the measurement in order to get accurate data. Values were recorded in $\mathrm{kg}$ (Alp \& Suna, 2020).

\subsubsection{Agility Tests}

All agility tests were taken with the wireless Fusion Sport, Birsbane, AUS brand Smartspeed with 0.001 timing accuracy with two gate systems.

\section{(1) T-Test}

Four cones were lined up on the track. When the player was given the command to start, he started from the cone "A", ran straight to the cone "B" and touched the cone with his right hand. Then he ran to the left towards the " $C$ " cone with side step and touched the "C" cone with his left hand, then to the right he touches the " $\mathrm{D}$ " cone with his right hand. Then, after touching the " $\mathrm{B}$ " cone with a side run and touching it with the left hand, it returned to the " $\mathrm{A}$ " cone with a run. As soon as you reach the cone "A", the stopwatch was stopped. In this study, the participant did 3 maximum repetitions with full rest. The best time of the participant was recorded (K1z1let, 2010; Pauole, 2000).

\section{(2) Pro-Agility Test}

The pro-agility agility test area, also known as the 20 -yard running test, was determined by placing markers 5 yards $(4.57 \mathrm{~m})$ to the left and right of the starting line. Photocell door was placed on the starting line. Repeated transition times could be taken in this way. The participant took his place at the starting line before the application started. When it was ready, it ended the test by touching the right pointer first, then the left one, passing through the baseline (Bayraktar, 2013).

\subsection{Procedure}

As the VTG continued with their routine volleyball training; regional plyometric trainings for the lower extremity were performed to the PTG for 6 weeks, 3 days a week, at least 30 minutes a day in addition to volleyball training. 


\subsubsection{Content of Regional Plyometric Training}

Zigzag Hops: The players were made to stand approximately 1-2 feet to the left of the agility ladder. Then they were made to jump on both feet and descend to the other side of the ladder. The exercise was repeated, they lowered their feet to the other side, and continued down the ladder like this. They were warned not to "double jump" on each landing and to keep ground contact time to a minimum.

Depth Jumps: The players stood with their feet shoulder-width apart on the box. Then they jumped out of the box and landed on both feet. They jumped high, reaching out with both hands as quickly as possible. When the players practice this plyometric exercise, they were warned and controlled about the jump should be vertical rather than horizontal; the short contact time with the ground and the soft landing.

Single Leg Tuck Jump: It was ensured that the pliometric exercise was the same as the tight jump exercise performed on one leg. Immediately after landing, the next jump was achieved with the same foot for minimum contact time with the ground and desired repetitions. Exercise was applied again for the other leg after resting.

\subsection{Statistical Analysis}

The data were analyzed by statistics program. The results of "Shapiro-Wilk" test was that the data showed normal distribution. Descriptive Statistics, Paired T-Test, and Independent T-Test were used for comparison. " $p<0.05$ " significance level was accepted for the results' evaluation.

\section{Results}

According to Table 1, which shows the results of groups' Paired T-Test, significant difference was found in PTG's results $(\mathrm{p}<0.05)$; but there was no difference in VTG' results $(\mathrm{p}>0.05)$.

Table 1. Results of groups' T-Test

\begin{tabular}{|l|l|l|l|l|}
\hline Groups (sec) & Test Sequence & Mean \pm SD & t & p \\
\hline \multirow{3}{*}{ VTG } & Pre-test & $9.89 \pm 0.71$ & \multirow{2}{*}{6.87} & \multirow{2}{*}{.197} \\
\cline { 2 - 5 } & Post-test & $9.81 \pm 0.69$ & & \multirow{2}{*}{7.41} \\
\hline \multirow{2}{*}{ PTG } & Pre-test & $9.82 \pm 0.55$ & $\mathbf{. 0 0 0}$ \\
\cline { 2 - 3 } & Post-test & $9.71 \pm 0.54$ & & \\
\hline
\end{tabular}

Table 2 shows the results of Pro-Agility Test. As shown in Table 2, difference was found significant in PTG's results $(\mathrm{p}<0.05)$; but no difference was found in VTG' results $(\mathrm{p}>$ $0.05)$. 
Table 2. Results of groups' Pro-Agility Test

\begin{tabular}{|c|c|c|c|c|}
\hline Groups (sec) & Test Sequence & $\operatorname{Mean} \pm$ SD & $\mathbf{t}$ & $\mathbf{p}$ \\
\hline \multirow{2}{*}{ VTG } & Pre-test & $6.38 \pm 0.67$ & \multirow{2}{*}{3.64} & \multirow{2}{*}{.251} \\
\hline & Post-test & $6.36 \pm 0.71$ & & \\
\hline \multirow{2}{*}{ PTG } & Pre-test & $6.32 \pm 0.34$ & \multirow{2}{*}{5.25} & \multirow{2}{*}{.000} \\
\hline & Post-test & $6.24 \pm 0.34$ & & \\
\hline
\end{tabular}

According to Table 3, which indicates the results of comparison of gruops' T-Test, no differences were found in each groups' pre- and post-test results $(p>0.05)$.

Table 3. Results of comparison of groups' T-Test

\begin{tabular}{|l|l|l|l|l|}
\hline T-Test (sec) & Groups & Mean \pm SD & t & p \\
\hline \multirow{3}{*}{ Pre-Test } & VTG & $9.89 \pm 0.71$ & \multirow{2}{*}{2.72} & \multirow{2}{*}{.169} \\
\cline { 2 - 5 } & PTG & $9.82 \pm 0.55$ & & \multirow{2}{*}{3.11} \\
\hline \multirow{2}{*}{ Post-Test } & VTG & $9.81 \pm 0.69$ & .157 \\
\cline { 2 - 4 } & PTG & $9.71 \pm 0.54$ & & \\
\hline
\end{tabular}

Table 4 shows Independent T-Test's results of Pro-Agility Test. As indicated Table 4, no differences were found in each groups' pre- and post-test results $(p>0.05)$.

Table 4. Results of comparison of groups' Pro-Agility Test

\begin{tabular}{|l|l|l|l|l|}
\hline Pro-Agility Test $(\mathbf{s e c})$ & Groups & Mean \pm SD & t & p \\
\hline \multirow{2}{*}{ Pre-Test } & VTG & $6.38 \pm 0.67$ & \multirow{2}{*}{1.97} & .103 \\
\cline { 2 - 5 } & PTG & $6.32 \pm 0.34$ & & \\
\hline \multirow{2}{*}{ Post-Test } & VTG & $6.36 \pm 0.71$ & \multirow{2}{*}{2.17} & .097 \\
\cline { 2 - 5 } & PTG & $6.24 \pm 0.34$ & & \\
\hline
\end{tabular}

\section{Discussion}

The effects of regional plyometric trainings on the agility performances of male volleyball players were investigated in this study. In our study, in the comparison of the $\mathrm{T}$ and 
Pro-Agility pre and post tests' values of the groups, significant difference was found in PTG's values $(\mathrm{p}<0.05)$, but no differences were found in VTG' values $(\mathrm{p}>0.05)$. Also, no differences were found as a result of the comparison of the T and Pro-Agility Test values $(\mathrm{p}>$ $0.05)$.

Since sprint performance requires the generation of explosive force in the lower extremity muscle groups, the ability of athletes to use and optimize elastic and neural properties after plyometric training is utilized (Akilandeswari \& Pushparajan, 2012). Agility is a complex feature that depends on many factors and is also supported by plyometric training that includes muscle adaptations (Markovic, 2007; Ozgul, 2018).

In a study investigating the effect of six-week plyometric training period on different agility test values, it was observed that plyometric training made a statistically significant difference in agility test values compared to the pre-training period (Váczi, 2013). Many researchers found that plyometric training periods positively affected the agility test values (Miller et al., 2006; Suna et al., 2016; Iş1ldak, 2020).

Some studies tested the effects of plyometric training on the agility of volleyball players. Lehnert et al. (2009) observed a significant increase in performance in shuttle running (6 mx $6 \mathrm{~m}$ ) in their study performed for eight weeks in women. In another study, it was observed that 12 -week plyometric training in young adult males significantly increased the agility of the athletes in shuttle running and improved the time to complete the shuttle run (Veličković et al., 2017). Studies prove that plyometric training increases agility.

Tillaar et al. (2015), in their study on 26 athletes, additionally applied for the plyometric training program twice a week. At the end of 6 weeks, they found an increase in agility tests in both groups. Erdoğan (2014) applied 8-week plyometric training in their study. Results of the evaluation indicated that, a significant increase in agility parameters was found. Baydemir et al. (2020) investigated the components of speed, quickness, and agility performance in amateur players in their study. They emphasized the significant and positive changes in agility parameters (Baydemir \& Yurdakul, 2020). Turna (2019) also found positive and significant changes in agility parameters.

In the study conducted by Sökmen (2018), difference was found to be statistically significant as a result of comparison in soccer players' test values. When the literature regarding our research is examined, the findings discussed support our study.

\section{Conclusion}

In conclusion, our study shows that plyometric training positively affects agility performances in volleyball players. Agility performance is a feature developed through plyometric training due to the increase in motor units and nerve conduction speed due to the increase in muscle strength and movement efficiency. Considering that plyometric trainings provide maximum contraction in the shortest time possible and its effect on the characteristics like sudden changes of location and direction in the volleyball, applying plyometric trainings may be thought to be effective in volleyball training programs. 


\section{References}

Akilandeswari, S., \& Pushparajan, A. (2012). Effect of Plyometric Training with Dynamic Stretching Programme on Upper Body Strength and Lower Body Strength of Female Volleyball Players. Int. J. Innov. Res. Dev., 1, 205-216.

Alp, M., \& Suna, G. (2020). Effects of interval sprint trainings on heart rate and $50 \mathrm{~m}$ swimming performances of young male swimmers. Journal of Education and Learning, 9(2), 242-247.

Arslan, T. (2013). The effect of plyometric training with weight vest and without vest on the vertical jump performance of 10-14 age group female volleyball players (Master Thesis, Süleyman Demirel University, Isparta).

Aydoğan, D. (2006). Comparison of the physical parameters of the junior and star players of some volleyball teams in İzmir province during the competition period (Master Thesis, Selçuk University, Konya).

Baacke, H. (2005). Handbook for Volleyball Training Senior Coaches and Teams. İstanbul: Çağrı Baskı Ambalaj San. Tic. Ltd. Şti. Voleybol Antrenörler Derneği Yayını.

Baydemir, B., \& Yurdakul, H. Ö. (2020). Components of speed, quickness and agility performance of amateur footballers. Akdeniz Spor Bilimleri Dergisi, 3(1), 63-71. https://doi.org/10.38021/asbid.733904

Baydemir, B., Cirasun, V., \& Yurdakul, H. Ö. Ö. (2020). The effect of strength training applied to football referees on speed, agility, aerobic and anaerobic capacity. Uluslararast Dağcılık ve Tırmanış Dergisi, 3(1), 15-26. https://doi.org/10.36415/dagcilik.726492

Bayraktar, I. (2013). Relationships between elite boxers' agility, speed, reaction and vertical jumping abilities. Akademik Bakış Dergisi, 35, 1-8.

Behm, D. G., Faigenbaum, A. D., Falk, B., \& Klentrou, P. (2008). Canadian society for exercise physiology position paper: Resistance training in children and adolescents. Appl. Physiol. Nutr. Metab., 33, 547-561. https://doi.org/10.1139/H08-020

Boreham, C. (2006). The physiology of sprint and power training. The physiology of Training (pp. 117-134). Edinburgh, London, New York, Oxford, Philadelphia, St. Louis, Sydney, Toronto: Churchill Livingstone Elsevier. https://doi.org/10.1016/B978-0-443-10117-5. $50011-8$

Cappa, D. F., \& Behm, D. G. (2013). Neuromuscular characteristics of drop and hurdle jumps with different types of landings. J. Strength Cond. Res., 27, 3011-3020. https://doi.org/ 10.1519/JSC.0b013e31828c28b3

Chu, D. (1992). Jumping In To Plyometrics. London: Prentice Hall Pub.

Craig, B. W. (2004). What is the scientific basis of speed and agility? Strength Cond. J., 26, 13-14. https://doi.org/10.1519/00126548-200406000-00002 


\section{Macrothink

Erdoğan, E., İnce, A., Dinçer, Ö., Sözen, H., Cevahircioğlu, B., \& Arı, E. (2014). The effect of plyometric training on some motor skills of students at Physical Education and Sports School. Prime Journal of Social Science, 3, 12.

Günay, E., Şıktar, E., \& Ş1ktar, E. (2017). Training Science. Ankara: Gazi Kitap Evi Tic. Ltd. Şti.

Isıldak, K. (2020). The effect of plyometric training on quickness, vertical jumping and long jump performance. Akdeniz Spor Bilimleri Dergisi, 3(1), 36-44. https://doi.org/10.38021/ asbid. 727497

Kizılet, A., Atılan, O., \& Erdemir, I. (2010). The effect of the different strength training on quickness and jumping abilities of basketball players between 12 and 14 age group. Journal of Physical Education and Sport Sciences, 12(2), 44-57.

Lehnert, M., Lamrová, I., \& Elfmark, M. (2009). Changes in speed ans strength in female volleyball players during and after a plyometric training program. Acta Univ. Palacki. Olomuc. Gymnica, 39, 59-66.

Markovic, G. (2007). Does plyometric training improve vertical jump height? A meta-analytical review. Br. J. Sports Med., 41, 349-355. https://doi.org/10.1136/bjsm.2007. 035113

Miller, J. M., Hilbert, S. C., \& Brown, L. E. (2001). Speed, quickness, and agility training for senior tennis players. Strength Cond. J., 23, 62-66. https://doi.org/10.1519/00126548-200110 000-00017

Miller, M. G., Herniman, J. J., Ricard, M. D., Cheatham, C. C., \& Michael, T. J. (2006). The effects of a 6-week plyometric training program on agility. Journal of Sports Science \& Medicine, 5(3), 459.

Muratlı, S., Şahin, G., \& Kalyoncu, O. (2005). Training and Competition. İstanbul: İstanbul Yaylım Yayıncılık.

Ozgul, F. (2018). Investigating Flexibility Effects on Vertical Jump of the Adolescent Athletes. Int. J. Sports Physiol. Educ., 4, 19-21.

Pauole, K., Madole, K., Garhammer, J., Lacourse, M., \& Rozenek, R. (2000). Reliability and validity of the T-Test as a measure of agility, leg power, and leg speed in college-aged men and women. $J$ of Strength and Conditioning Research, 14(4), 443-450. https://doi.org/ 10.1519/00124278-200011000-00012

Radcliffe, J. C., \& Faratinos, R. C. (1999). High-Powered Plyometrics (pp. 11-12). Human Kinetics.

Silva, A. F., Clemente, F. M., Lima, R., Nikolaidis, P. T., Rosemann, T., \& Knechtle, B. (2019). The effect of plyometric training in volleyball players: A systematic review. International Journal of Environmental Research and Public Health, 16(16), 2960. https://doi.org/10.3390/ijerph16162960 


\section{Macrothink}

Sökmen, A. T. (2018). Relationship of anaerobic power with different agility and speed tests in young football players (Master's thesis, Kırıkkale Üniversitesi).

Suna, G., Beyleroğlu, M., \& Hazar, K. (2016). Comparison of aerobic, anaerobic power features basketball and handball team players. Beden Ĕ̈itimi ve Spor Bilimleri Dergisi, 10(3), 379-385.

Turna, B. (2019). The effects of competition period training on selected physical properties of football players. Akdeniz Spor Bilimleri Dergisi, 2(1), 15-27.

Turnagöl, H. (1995). Volleyball and Physiology-1. Voleybol Bilim ve Teknoloji Dergisi, 2(5), 13-17.

Váczi, M. T. (2013). Short-Term high intensity plyometric training program improves strength, power and agility in male soccer players. Journal of Human Kinetics, 36(1), 17-26. https://doi.org/10.2478/hukin-2013-0002

van den Tillaar, R., Waade, L., \& Roaas, T. (2015). Comparison of the effects of 6 weeks of squat training with a plyometric training programme upon different physical performance tests in adolescent team handball players. Acta Kinesiologiae Universitatis Tartuensis, 21, 75-88. https://doi.org/10.12697/akut.2015.21.07

Veličković, M., Bojić, I., \& Berić, D. (2017). The effect of programmed training on development of explosive strength in female volleyball players. Facta Univ. Ser. Phys. Educ. Sport, 15, 493-499. https://doi.org/10.22190/FUPES1703493V

Young, W. B., McDowell, M. H., \& Scarlett, B. J. (2001). Specificity of sprint and agility training methods. J. Strength Cond., 15, 315-319. https://doi.org/10.1519/00124278-20010 8000-00009

\section{Copyright Disclaimer}

Copyright for this article is retained by the author(s), with first publication rights granted to the journal.

This is an open-access article distributed under the terms and conditions of the Creative Commons Attribution license (http://creativecommons.org/licenses/by/3.0/). 